A N N A L E S

UNIVERSITATIS MARIAE CURIE-SKŁODOWSKA

LUBLIN - POLONIA

VOL. LXXV

SECTIO B

2020

OSKAR WOLSKI

https://orcid.org/0000-0001-8790-1677

Uniwersytet Łódzki

Wydział Nauk Geograficznych

ul. Kopcińskiego 31, 90-142 Łódź

oskwolski@gmail.com

\title{
Zastosowanie narzędzi GIS do określenia lokalnej specyfiki procesu rozwoju obszarów wiejskich. \\ Studium aktywności społeczności lokalnych w programie odnowy wsi w województwie wielkopolskim
}

The Use of GIS Tools to Determine the Local Specifics of Rural Development. The Case of the Participation of Local Communities in the Rural Renewal Programme in the Wielkopolskie Region in Poland

\begin{abstract}
Rural development at the local level is a complex process, in which various actors are involved and various practices are performed. Nowadays, an important role in this process is assigned to rural communities, whose participation is essential. While in terms of the programming of rural development, it is still the rural area which is in the centre of attention, the theoretical concepts of rural development suggest that the process is even more local and specific to each village. This triggers the discussion whether the interpretation of the practices of rural development can be different depending on which spatial analysis unit is selected. The main aim of the paper was to empirically verify this hypothesis, on the example of the participation of local communities in the rural renewal programme in the Wielkopolskie Region. Hot spot analysis, based on spatial statistical methods, was performed. The discussion of the GIS tools - that can be used for this analysis - in the research on rural development was the second aim of the paper. The third aim was to contribute to the state of knowledge on the rural development fostered beyond the European Union policies. The main conclusion is that the most engaged communities tend to cluster, and such clusters are a specific kind of networks, which exist notwithstanding the administrative borders of rural areas. Both neighbourhood effect and cognitive distance are crucial for participation. Finally, the difficulties in the application of the tools used were identified, and these are related to the quantification of social phenomena and the selection of parameters of the very spatial statistical analysis.
\end{abstract}

Keywords: rural development; local development; rural renewal; GIS; spatial statistics; hot spot analysis 


\begin{abstract}
Abstrakt: Rozwój obszarów wiejskich na poziomie lokalnym jest zagadnieniem niezwykle złożonym, co dotyczy zarówno uczestniczących w tym procesie aktorów, jak i praktyk przez nich podejmowanych. Współcześnie istotną rolę w tym procesie przypisuje się społeczności wiejskiej, a jej aktywność w działaniach na rzecz rozwoju uważana jest za kluczową. Podczas gdy w programowaniu rozwoju obszarów wiejskich centrum zainteresowania to obszar wiejski, koncepcje tego rozwoju wskazują na specyficzność tego procesu już na poziomie wsi. Daje to przyczynek do zastanowienia się, czy interpretacja określonych praktyk rozwoju obszarów wiejskich rzeczywiście może się różnić w zależności od przyjętej jednostki przestrzennej analizy. Empiryczna weryfikacja tej tezy na przykładzie aktywności społeczności lokalnych w programie odnowy wsi w województwie wielkopolskim była głównym celem pracy. Zastosowano w niej analizę hot spot, która opiera się na metodach statystyki przestrzennej. Dyskusja wykorzystania narzędzi GIS, pozwalających na przeprowadzenie tej analizy, w badaniach nad rozwojem obszarów wiejskich była drugim celem pracy. Trzecim zaś była kontrybucja do stanu wiedzy na temat rozwoju obszarów wiejskich realizowanego poza polityką Unii Europejskiej. Najważniejszym wnioskiem z przeprowadzonych badań jest to, że społeczności najbardziej aktywne tworzą skupiska, które stanowią specyficzną formę sieci powiązań, a ich istnienie jest niezależne od przebiegu granic administracyjnych obszarów wiejskich. Na aktywność tę decydujący wpływ mają jednocześnie efekt sąsiedztwa i bliskość poznawcza. Ponadto zidentyfikowano trudności w zastosowaniu wspomnianych narzędzi - problem kwantyfikacji zjawisk społecznych oraz dobór parametrów samej analizy statystyczno-przestrzennej.
\end{abstract}

Słowa kluczowe: rozwój obszarów wiejskich; rozwój lokalny; odnowa wsi; GIS; statystyka przestrzenna; analiza hot spot

\title{
WSTĘP. ROZWÓJ OBSZARÓW WIEJSKICH JAKO ROZWÓJ LOKALNY
}

Rozwój obszarów wiejskich jest jednym z wiodących tematów w geografii wsi (Woods 2005), który ewoluował, odzwierciedlając przemiany wsi. Zachodzą one w różnym stopniu na różnych obszarach wiejskich, a dotyczą gospodarki (odchodzenie od rolnictwa na rzecz wielofunkcyjności), tkanki społecznej (wiele grup aktorów wiejskich, a nie tylko chłopi) i kultury (zmiana wartości życia wiejskiego i stylów życia) (np. Hoggart, Black, Buller 1995; Ilbery 1998; Woods 2009), przez co kolejno zmieniały się przedmiot wsparcia polityk rozwoju, ich adresaci i cele. Jeśli do powyższego dodać, że rozwój obszarów wiejskich jest procesem zachodzącym na różnych szczeblach - od europejskiego po lokalny (van der Ploeg i in. 2000), to jasne jest, że na każdym z tych poziomów zarządzania istnieje wiele specyficznych praktyk społecznych i ekonomicznych, odzwierciedlających zróżnicowanie obszarów wiejskich, typowych dla jednego obszaru, lecz nietypowych dla innego (van der Ploeg, Renting 2000; Halfacree 2006).

Współczesne zainteresowanie politykami terytorialnymi przyczyniło się do zmian podstaw teoretycznych i metodologicznych studiów nad rozwojem obszarów wiejskich (Hodge, Midmore 2008), które w większym stopniu 
skoncentrowane są na „miejscach” (zob. Wójcik 2014). Podejmowane poprzez polityki rozwoju działania zawsze realizowane są w konkretnym miejscu, przez konkretnych ludzi i dla konkretnych ludzi. Próba zrozumienia, czym rzeczywiście jest rozwój obszarów wiejskich, wymaga zatem prowadzenia badań empirycznych w skali lokalnej (van der Ploeg, Ye, Schneider 2015).

Poziom lokalny, obok poziomu regionalnego, jest tym, na którym najczęściej prowadzi się analizy strategii czy programów (Knickel, Renting 2000). Wynika to z pewnej jego specyfiki, którą M. Moseley (2003, s. 8) thumaczy w następujący sposób: ,[...] obszar lokalny powinien być wystarczająco mały, by zachować »sens miejsca«, zaangażowanie społeczności lokalnych [...], ale także wystarczająco duży, by prowadzić gospodarkę opartą na korzyściach skali i zapewniać określone usługi [...]”. Tak rozumiany obszar lokalny odpowiada obszarowi wiejskiemu, zamieszkiwanemu przez wspólnotę, której przewodzi samorząd posiadający instrumenty prawne i ekonomiczne, aby zaspokajać jej potrzeby i który stanowi jednostkę terytorialną (w Polsce jest to gmina). W programowaniu rozwoju tak rozumiany poziom lokalny tradycyjnie odgrywa kluczową rolę, ponieważ to samorządy lokalne są w istotnym stopniu odpowiedzialne za realizację polityk.

Niemniej nowe koncepcje rozwoju obszarów wiejskich akcentują przede wszystkim rolę społeczności lokalnych w powodzeniu tego procesu, przy czym „lokalny” nie jest tutaj rozumiany jedynie jako odnoszący się do wspomnianego obszaru wiejskiego, lecz przede wszystkim odnosi się do poszczególnych wsi. Do koncepcji tych można zaliczyć inteligentne wioski (smart villages) (European Network for Rural Development 2018; Visvizi, Lytras 2018; Wolski, Wójcik 2019) oraz odnowę wsi (Wilson 1999; Chigbu 2012), a częściowo także inteligentny rozwój obszarów wiejskich (smart rural development) (Naldi, Nilsson, Westlund, Wixe 2015). Zgodnie z nimi rozwój obszarów wiejskich może być skutecznie realizowany już na poziomie pojedynczej wsi, na którym istnieją też specyficzne potrzeby, których dotyczy podejmowana interwencja.

Dlatego pytanie o to, jak „lokalny” jest poziom lokalny współcześnie - pomimo globalizacji gospodarki, przemian kulturowych i mobilności społeczeństwa - wciąż nie traci na znaczeniu. Przeciwnie, w dobie technologii cyfrowych wspierających rozwój obszarów wiejskich, nowych kanałów komunikacji, powszechnej partycypacji społeczności wiejskich w procesie rozwoju i governance pytanie to zyskuje nowe znaczenie, bowiem wszystkie one umacniają pozycję społeczności poszczególnych wsi i sprzyjają subsydiarności. Nie jest więc przypadkiem, że jedną z najbardziej dyskutowanych praktyk w procesie rozwoju obszarów wiejskich jest także aktywność w nim społeczności wiejskich (np. Morris 1998; Ray 2000; Shortall 2008). 
Jeśli specyficzne praktyki rozwoju obszarów wiejskich, takie jak aktywność społeczności wiejskich, występują na każdym szczeblu zarządzania rozwojem i jeśli rozwój ma swój początek w każdej pojedynczej wsi, to interpretacja tych praktyk poprzez agregację do poziomu obszaru wiejskiego - czyli do jednostki dominującej w praktyce programowania rozwoju obszarów wiejskich - może zniekształcać ich obraz, a nawet spłycać zróżnicowanie. Innymi słowy, wybór jednostki przestrzennej analiz odgrywa istotną rolę w badaniach procesów rozwoju obszarów wiejskich, jednakże zdaniem autora problem ten występuje już w badaniach w skali lokalnej, w badaniach ,miejsc”, a nie tylko w skali regionalnej, krajowej czy kontynentalnej.

Głównym celem niniejszej pracy jest empiryczna weryfikacja, czy aktywność społeczności lokalnych rzeczywiście jest praktyką specyficzną na poziomie wsi, tak jak wynika to z najnowszych koncepcji rozwoju obszarów wiejskich. Problem interpretacji zjawisk w przestrzeni w zależności od doboru jednostek przestrzennych jest problemem tradycyjnym w naukach geograficznych, jednak dotąd nie podjęto go w kontekście badań procesów rozwoju obszarów wiejskich na poziomie lokalnym. Nie jest on jedynie teoretyczny, gdyż weryfikacja postulatów uczynienia poziomu lokalnego ,jeszcze bardziej lokalnym”, a obszarów wiejskich - „miejscami”, może stanowić istotną kontrybucję do metodologii programowania polityk obszarów wiejskich.

Aby przeprowadzić badania aktywności społeczności lokalnych w rozwoju obszarów wiejskich jako zróżnicowanej przestrzennie praktyki, należało odpowiednio zaplanować proces badawczy. Po pierwsze, konieczne było uwzględnienie takiego programu rozwoju tych obszarów, który zapewnia tym społecznościom pełnię możliwości uczestnictwa, np. poprzez możliwość samodzielnego aplikowania o środki finansowe na realizację działań rozwojowych (zob. Storey 1999). Jednocześnie społecznościami aplikującymi o nie musiały być społeczności zamieszkujące poszczególne wsie. Kryteria te spełnia program odnowy wsi w województwie wielkopolskim, który wybrano jako studium przypadku. Wybór ten uzasadniają także przesłanki teoretyczne. Badania na temat rozwoju obszarów wiejskich realizowanego poza mechanizmami unijnymi wydają się bowiem istotne z perspektywy budowania całościowego programu badawczego dla studiów nad rozwojem obszarów wiejskich (van der Ploeg i in. 2000). Dodatkowo wciąż obserwowany jest niedostatek prac podejmujących problemy rozwoju obszarów wiejskich na szczeblu lokalnym (Brennan, Flint, Luloff 2009). Z tego powodu kontrybucja do stanu wiedzy na temat rozwoju obszarów wiejskich realizowanego poza mechanizmami Unii Europejskiej stała się kolejnym celem pracy.

Po drugie, realizacja celu głównego pracy wymagała zastosowania odpowiednich metod i narzędzi, które pozwalają na eksplorację zjawiska według 
różnych jednostek przestrzennych przy jego określonych atrybutach, mając przy tym na względzie, że określone praktyki tego rozwoju cechują się przestrzenną koncentracją (Knickel, Renting 2000). Warunki te spełniają m.in. analizy klastrów, do których można wykorzystać narzędzia GIS. Choć nie są one powszechnie wykorzystywane w badaniach nad rozwojem obszarów wiejskich, mogą stanowić alternatywę i dopełnienie bardziej popularnych metod wywodzących się z nauk społecznych i ekonomicznych (zob. Hodge, Midmore 2008; Erden, Kaya, Öcal 2015). W takim kontekście demonstracja i dyskusja zastosowania tych narzędzi stanowi ostatni, mający charakter metodologiczny, cel pracy.

Układ artykułu jest następujący. Po wstępie zostały wskazane powiązania między zagadnieniami terytorialnego wymiaru polityk rozwoju obszarów wiejskich - ze szczególnym uwzględnieniem poziomu lokalnego - i metodologią ich badań oraz między zagadnieniami polityk regionalnych realizowanych poza mechanizmami unijnymi na przykładzie programów odnowy wsi i rolą aktywności społeczności wiejskich w procesie rozwoju wsi. Przedstawione w tej części opracowania współcześnie dyskutowane problemy metodologiczne stanowią wstęp do opisu zastosowanych w pracy metod statystyki przestrzennej i narzędzi GIS. Omówiono również obszar badan - województwo wielkopolskie wraz z realizowanym na jego obszarze programem odnowy wsi, co wiąże wcześniej dyskutowane aspekty teoretyczne z konkretnymi działaniami podejmowanymi w obrębie polityk regionalnych rozwoju obszarów wiejskich. Następnie zaprezentowano rezultaty przeprowadzonych badań, a także przedyskutowano je w kontekście zagadnień metodologicznych oraz teorii działań rutynowych i sieci. Całość zamykają wnioski.

\section{ZAGADNIENIA TEORETYCZNE}

\section{Polityki terytorialne i praktyki rozwoju obszarów wiejskich - zarys dylematów metodologicznych}

Współczesna polityka rozwoju obszarów wiejskich jest rezultatem ewolucji, którą można podsumować jako odejście od polityki sektorowej, wspierającej głównie rolnictwo, na rzecz wspierania zarówno innych gałęzi wiejskiej gospodarki, jak i społecznie zróżnicowanego grona beneficjentów zamieszkujących wieś (np. Baldock, Dwyer, Lowe, Petersen, Ward 2001; OECD 2006). Ewolucja ta wymaga istotnych zmian w metodologii badań rozwoju obszarów wiejskich, które mają przeciwdziałać temu, by nie był on jedynie zagadnieniem praktycznym, pozbawionym teorii (van der Ploeg i in. 2000). Sektorowe wsparcie rolnictwa, oparte na działaniach na rzecz wzrostu produkcji rolniczej, zatrudnienia w rolnictwie i dochodów rolników, bada się głównie w świetle modeli 
biznesowych gospodarstw rolnych i przedsiębiorstw wiejskich oraz w kontekście przepływu dóbr i towarów przez nie wytwarzanych. W obu przypadkach wykorzystywane są głównie analizy kluczowych wskaźników efektywności (Ellis, Biggs 2001; Hodge, Midmore 2008).

Polityki terytorialne, jako że w założeniu służą rozwiązywaniu problemów różnych obszarów, są zróżnicowane, ponieważ istnieją nie tylko krajowe czy regionalne style regulacji prawnych (Flyn, Marsden 1995; van der Ploeg i in. 2000), lecz także mniej formalne mikropolityki (McAreavey 2006). Rozwój przez nie wspierany przebiega więc w konsekwencji według różnych trajektorii (por. Terluin 2003), co współcześnie wiąże się z różnymi zasobami lokalnymi różnych obszarów (Stanny 2013). Jak argumentowano we wstępie, specyficzne praktyki mają miejsce na wszystkich szczeblach zarządzania rozwojem, jednak to praktyki rozwoju lokalnego cechują się największym zróżnicowaniem. Aby zilustrować ich zróżnicowanie w Polsce w kontekście obszarów wiejskich, warto wspomnieć o badaniach naukowych poświęconych takim praktykom, jak chociażby przeciwdziałanie konfliktom przestrzennym (np. Michałowska 2008; Dmochowska-Dudek, Bednarek-Szczepańska 2018), udział interesariuszy w zawiązywaniu partnerstw terytorialnych (np. Furmankiewicz, Thompson, Zielińska 2010; Kołomycew, Pawłowska 2013), wdrażanie innowacji w środowisku wiejskim (np. Zajda 2017; Pałka-Łebek, Brambert 2018), pozyskiwanie wiedzy przez wybrane grupy społeczne zamieszkujące wieś (np. Wójcik, Czapiewski, Jeziorska-Biel 2019) czy wreszcie podejmowana w pracy aktywność społeczności lokalnych (np. Pieczonka 2018). Każda z tych praktyk jest przedmiotem polityk terytorialnych, ale do ich badań można stosować bardzo różne podejścia badawcze, oparte na metodach zarówno ilościowych, jak i jakościowych. W tym kontekście na pierwszy plan wysuwa się potrzeba stosowania takich procedur badawczych, które mogą być powtórzone, jako że wówczas otrzymane rezultaty mogą zostać wykorzystane do systematyzacji wiedzy na temat danej praktyki. W kontekście zastosowania narzędzi GIS do analiz klastrów wiąże się to z odpowiednim opisem parametrów tych analiz i ich czytelnym przełożeniem na podejmowany problem badawczy.

2. Odnowa wsi jako instrument rozwoju obszarów wiejskich realizowanego poza politykami Unii Europejskiej oraz rola społeczności lokalnych w procesie rozwoju obszarów wiejskich

Programy odnowy wsi stanowią specyficzny instrument realizacji polityk rozwoju obszarów wiejskich. Działania odnawiające dotyczą bowiem nie tylko przestrzeni materialnej wsi i wsparcia rozwoju gospodarczego, lecz także szeroko rozumianych aspektów społeczno-kulturowych, np. budowy więzi społecznych, 
zachowania dziedzictwa materialnego i niematerialnego wsi, a nawet rozwoju duchowego jej mieszkańców (Wieruszewska 1992; Knievel 1997; Chigbu 2012). W dużej mierze społeczny wymiar działań z zakresu odnowy wsi wymaga jednak zaangażowania w proces społeczności lokalnych (Chigbu 2012; Idziak, Wilczyński 2013), co jest możliwe dzięki przyjętym zasadom funkcjonowania programów. Po pierwsze, podstawową jednostką przestrzenną działań w odnowie jest wieś. Po drugie, w procesie odnowy społeczność lokalna jest zarówno aktorem, jak i beneficjentem działań, w efekcie czego charakter działań jest oddolny. Po trzecie, poza wsparciem finansowym kształtuje się kompetencje liderów wiejskich oraz postuluje się wymianę doświadczeń (Wolski 2017).

Postulaty zaangażowania społeczności lokalnych w planowanie rozwoju wsi pojawiły się na dobre w programach odnowy w latach 90. XX w. (Magel 2000) i były inspirowane ówczesnymi postępami w teorii rozwoju obszarów wiejskich. Mowa tutaj zwłaszcza o takich zagadnieniach, jak partycypacja w rozwoju obszarów wiejskich oraz kapitał społeczny mieszkańców wsi i partnerstwa lokalne, których pozytywna rola w powodzeniu podejmowanych inicjatyw odnowy wsi została również potwierdzona badaniami empirycznymi (Murray, Dunn 1995; Wilczyński 2003; Chigbu 2012; McArdle 2012; Huttner 2013).

W praktyce działań na rzecz rozwoju lokalnego powyższe urzeczywistniane jest poprzez upodmiotowienie społeczności lokalnych i skuteczną realizację zasady subsydiarności. W odnowie wsi odbywa się to poprzez możliwość samodzielnego aplikowania przez społeczności o środki finansowe, samodzielne decydowanie, na co je przeznaczyć oraz umożliwienie tworzenia struktur nieformalnych (Idziak, Wilczyński 2013).

Przedstawione powyżej, choć w zarysie, zagadnienia teoretyczne pozostają w ścisłym związku. Z szerokiego spektrum zagadnień teoretycznych i praktycznych rozwoju obszarów wiejskich wybrano te dotyczące polityk regionalnych. W szczególności mowa o politykach, które w centrum uwagi stawiają „lokalność" i lokalny wymiar działań. Następnie spośród tych polityk wybrano te, które wspierają upodmiotowienie społeczności lokalnych i przypisują im centralną rolę w procesie. W kontekście rozwoju obszarów wiejskich te cechy polityk posiada odnowa wsi. Stosując metodę studium przypadku, autor w niniejszym opracowaniu eksploruje aktywność społeczności wiejskich w programie odnowy wsi, rozumianą jako jedna ze specyficznych praktyk rozwoju obszarów wiejskich na poziomie lokalnym, nie pozostając przy tym obojętnym na problem powtarzalności procedur badawczych, co prowadzi do kontrybucji do teorii i metodologii programowania rozwoju obszarów wiejskich. 


\section{ZAGADNIENIA METODYCZNE}

\section{Zastosowane metody i narzędzia badań}

Poza metodą studium przypadku (zob. Babbie 2004; Rice 2010) w pracy zastosowano wybrane narzędzia GIS, które zapewniają powtarzalność procesu badawczego przy okazji badań różnych „miejsc”.

Spośród narzędzi GIS do badań relacji między jednostkami przestrzennymi, w których zachodzą określone zjawiska, wykorzystuje się te oparte na statystyce przestrzennej. Jest ona „typem analizy przestrzennej, której celem jest wyjaśnienie wzorców zachowań człowieka w przestrzeni za pomocą prawideł matematyki i geometrii, to znaczy za pomocą analizy lokalizacyjnej” (Mayhew 2005). Jeśli obecność badanego zjawiska w jednej jednostce przestrzennej powoduje zwiększanie się lub zmniejszanie prawdopodobieństwa występowania tego samego zjawiska w innych jednostkach, to mowa o autokorelacji przestrzennej (Bivand 1980). Na istnieniu takich zależności oparte są analizy klastrów (Anselin, Cohen, Cook, Gorr, Tita 2000; Mitchell 2005).

W pracy zastosowano analizę hot spot, która dla określonego zbioru obiektów posiadających pewne atrybuty identyfikuje statystycznie istotne hot i cold spoty, to znaczy obiekty wyróżniające się dodatnio lub ujemnie na tle sąsiednich, przy zastosowaniu statystyki Getisa i Orda (Getis-Ord $G i^{*}$ ) (Getis, Ord 1992; Mitchell 2005; Zhu 2016; zob. także dla opisu formuł matematycznych). Tak jak w przypadku każdej statystyki przestrzennej do przeprowadzenia tej analizy wymagane jest posiadanie dwóch typów informacji na temat badanych obiektów: lokalizacji i atrybutu (Goodchild, Haining, Wise 1992). Obiektami w przeprowadzonych badaniach były gminy i sołectwa (obręby ewidencyjne), które zostały odwzorowane według granic administracyjnych jako poligony. W tym celu wykorzystano dane z państwowego rejestru granic i powierzchni jednostek podziałów terytorialnych kraju, udostępniane przez Główny Urząd Geodezji i Kartografii. Lokalizację gmin i sołectw reprezentował centroid (środek geometryczny) (zob. Deakin, Bird, Grenfell 2002; ESRI 2018), który został także wykorzystany do geokodowania obiektów - niezbędnego dla przeprowadzenia analizy hot spot. Atrybutem przypisanym tym obiektom była aktywność społeczności wiejskich w programie odnowy wsi w województwie wielkopolskim, którą skwantyfikowano jako liczbę zrealizowanych przez nie projektów. Wartość atrybutu poddano standaryzacji. Dane na temat liczby i rozmieszczenia projektów pozyskano bezpośrednio od Urzędu Marszałkowskiego Województwa Wielkopolskiego - operatora programu odnowy wsi. Operacje statystyczno-przestrzenne, geokodowanie i symbolizację wykonano w środowisku ESRI ArcGIS 10.2.1. 
Parametry analizy hot spot zostały zdefiniowane następująco. Wejściową klasą obiektów była warstwa $\mathrm{z}$ geokodowanymi gminami i sołectwami, natomiast wejściowym polem analizy była liczba projektów zrealizowanych przez społeczności lokalne je zamieszkujące. W pracy testowano dwie metody konceptualizacji relacji przestrzennych: odwrotnego dystansu (inverse distance) i stałego dystansu (fixed distance), co wynika z toczonej na ten temat dyskusji (Zhu 2016; Sánchez-Martín, Rengifo-Gallego, Blas-Morato 2019). Odwrotny dystans zakłada, że obiekty wpływają na wszystkie inne obiekty zbioru, jednakże im sąsiedztwo jest bliższe, tym większe wagi przypisywane są obiektom. W przypadku stałego dystansu obiekty w zbiorze wpływają na siebie, ale tylko do określonego zakresu przestrzennego (distance band). Obiekty mieszczące się w tym zakresie posiadają te same wagi, podczas gdy obiekty poza nim nie wpływają na obliczenia. Wartość zakresu powinna być przy tym na tyle duża, by każdy obiekt posiadał co najmniej jednego sąsiada, co uważa się za kluczowy warunek poprawności analiz statystyczno-przestrzennych (Mitchell 2005; Scott, Janikas 2009; ESRI 2019). Przekładając powyższe na podjęty problem badawczy, w pierwszym przypadku zakłada się, że bezpośrednie lub bliskie sąsiedztwo nie jest niezbędne; równie istotna może być bliskość, lecz definiowana także w kategorii bliskości poznawczej (zob. Noteboom 2000; Boschma 2005). W drugim przypadku zakłada się, że na aktywność społeczności wiejskich zamieszkujących daną gminę lub sołectwo wpływa (poza czynnikami endogenicznymi) w pierwszej kolejności aktywność najbliższych sąsiadów, a więc bliskość geograficzna, co dalej można wiązać z efektem sąsiedztwa (zob. Faber, Sharkey 2015). W przeprowadzonej analizie wartość zakresu, do którego obiekty w zbiorze wpływały na siebie w przypadku, gdy metodą konceptualizacji relacji przestrzennych był stały dystans, wyniosła 16397 m, gdy wejściową klasą obiektów były gminy, natomiast $5928 \mathrm{~m}$, gdy były nią sołectwa. Zakres ten był domyślnie wyliczony przez wykorzystane oprogramowanie i w zdecydowanej większości zapewnił każdemu obiektowi od trzech do czterech sąsiadów. Jeśli chodzi o metodę obliczania odległości, wybrano odległość Euklidesową (kosztem odległości Manhattan, nazywanej też miejską). Tym samym założono, że na tworzenie się skupisk aktywnych społeczności wiejskich nie wpływają bariery geograficzne. Rozkład obiektów nie był zaburzony wskutek doboru próby, dlatego nie stosowano dodatkowej standaryzacji, jaką oferowało wykorzystane oprogramowanie.

\section{Obszar badań}

Województwo wielkopolskie zamieszkuje niespełna 3,5 mln osób, z czego ponad 1,5 mln mieszka na obszarach wiejskich. Województwo podzielone jest na 226 gmin, w tym 94 to gminy miejsko-wiejskie, a 113 to gminy wiejskie. 
To właśnie na ich obszarach (z wyłączeniem miast w gminach miejsko-wiejskich) realizowany jest program odnowy wsi. Według A. Rosnera i M. Stanny (2014) gminy miejsko-wiejskie i wiejskie województwa należą do najbardziej rozwiniętych pod względem społeczno-gospodarczym w kraju, zajmują bowiem - uśredniając - szóstą lokatę (na 16 województw). Spośród 207 takich gmin aż 180 to gminy bardzo wysoko, wysoko lub przeciętnie rozwinięte. Jeśli chodzi o strukturę ich gospodarki, największa ich liczba (100) to gminy wielofunkcyjne, cechujące się równowagą sektorów, a w dalszej kolejności są to gminy, w których dominuje rolnictwo wielkoobszarowe (40) oraz gminy z przewagą funkcji rolniczej (35). Poza tym 23 gminy są zurbanizowane lub silnie zurbanizowane. Tylko 9 gmin cechuje się dominacją rolnictwa tradycyjnego.

Wysoki poziom rozwoju społeczno-gospodarczego oraz struktura gospodarki gmin miejsko-wiejskich i wiejskich nieoparta jedynie na rolnictwie wpłynęły na specyfikę programu odnowy wsi, który w tym województwie realizowany jest od 2010 r. W założeniu program ten nie miał wspierać ekonomicznej funkcji rolnictwa, a rozwój społeczno-gospodarczy ogółem miał być wspierany za pomocą niewielkich inwestycji, głównie w infrastrukturę społeczną (renowacja i wyposażenie świetlic wiejskich i domów kultury, tworzenie zaplecza sportowego, turystycznego i rekreacyjnego). W dalszej kolejności projekty miały na celu: promowanie wsi lub obszaru wiejskiego, wsparcie wytwarzania produktów lokalnych i organizowanie imprez kulturalnych; zagospodarowanie przestrzeni publicznych; propagowanie dziedzictwa kulturowego. Powyższe działania, w większości inwestycyjne, uzupełniane są „miękkimi” instrumentami, takimi jak organizacja szkoleń dla liderów wiejskich i warsztatów dla społeczności wiejskich na temat planowania strategii rozwoju (Wielkopolska Odnowa Wsi 2013-2020; Wolski 2017).

Do końca 2018 r. w ramach programu odnowy wsi w województwie wielkopolskim zrealizowano 1332 projekty w 826 wsiach (sołectwach) znajdujących się na obszarze 170 gmin (zarówno miejsko-wiejskich, jak i wiejskich), dzięki czemu program wielkopolski jest tym, który obok programu dolnośląskiego dotarł do największej liczby mieszkańców wsi. Biorąc pod uwagę, że poziom rozwoju obszarów wiejskich województwa nie jest bardzo zróżnicowany, nie wpływał on $\mathrm{w}$ istotnym stopniu na różnice $\mathrm{w}$ zaangażowaniu społeczności lokalnych w proces odnowy wsi, co jest warunkiem wstępnym realizacji przedsięwzięć. Tym samym można założyć, że kluczowa dla tego zaangażowania była inicjatywność społeczności lokalnych. 


\section{REZULTATY: GIS W BADANIACH AKTYWNOŚCI SPOŁECZNOŚCI LOKALNYCH}

Przeprowadzenie analizy hot spot zostało poprzedzone wstępną analizą danych na temat liczby projektów zrealizowanych przez społeczności lokalne według wsi i gmin. Jej rezultaty zasugerowały przeprowadzenie dalszych badań dla obu tych jednostek przestrzennych z osobna, a wraz z zagadnieniami zaprezentowanymi we wstępie do pracy skłoniły autora do badań skupisk i wybrania analizy hot spot jako reprezentującej narzędzia GIS, których eksplorację i omówienie w kontekście studiów wiejskich praca ma na celu. Z tego względu za istotne uznano ich omówienie. Następnie zaprezentowano rezultaty zasadniczej części przeprowadzonych badań. Są to rezultaty serii analiz hot spot wykonanych dla dwóch klas obiektów - gmin i sołectw, a także dla dwóch metod konceptualizacji relacji przestrzennych - odwrotnego i stałego dystansu.

\section{Ustalenia wstępne}

Ryciny 1 i 2 pokazują rozkład przestrzenny projektów odnowy wsi zrealizowanych przez społeczności lokalne, odpowiednio według gmin i wsi w województwie wielkopolskim. W obu przypadkach można dostrzec pewne obszary podwyższonej aktywności społeczności lokalnych - w południowej i południowo-wschodniej części obszaru badań, a w mniejszym stopniu na północy i zachodzie. Jednocześnie w obu przypadkach liczba zrealizowanych projektów nie wynikała z liczby mieszkańców odpowiednio gmin i wsi, co przypuszczalnie mogło tłumaczyć tę aktywność (r-Pearsona $=0,21)$. Rezultaty globalnej statystyki I Morana wskazują dodatkowo, że w pierwszym wypadku zjawisko ma charakter losowy $(\mathrm{z}=1,14$ przy odwrotnym dystansie oraz $\mathrm{z}=0,74$ przy stałym dystansie), natomiast $\mathrm{w}$ drugim wystąpiła silna tendencja do skupiania się $(z=3,37 \text { przy odwrotnym dystansie oraz } \mathrm{z}=28,03 \text { przy stałym dystansie })^{1}$.

Liczba projektów zrealizowana na obszarze gmin i sołectw była zróżnicowana (ryc. 1 i 2). W województwie wielkopolskim jest ponad 4500 wsi (sołectw), z czego w 826 (18\%) zrealizowano przynajmniej jeden projekt. Spośród tych 826 wsi w $523(63,3 \%)$ zrealizowano tylko jeden projekt, a jedynie w $10(1,2 \%)$ - więcej niż pięć (najbardziej aktywna społeczność zrealizowała 12). Aktywność społeczności w programie była więc ograniczona do niespełna $1 / 5$ wszystkich wsi, a eliminując z tej puli społeczności aktywne incydentalnie (czyli te, które zrealizowały tylko jeden projekt od momentu zainicjowania programu) - jedynie

1 Przy czym należy mieć na uwadze, że rezultaty globalnej i lokalnej autokorelacji przestrzennej są niezależne od siebie (zob. np. Mordwa 2013). 


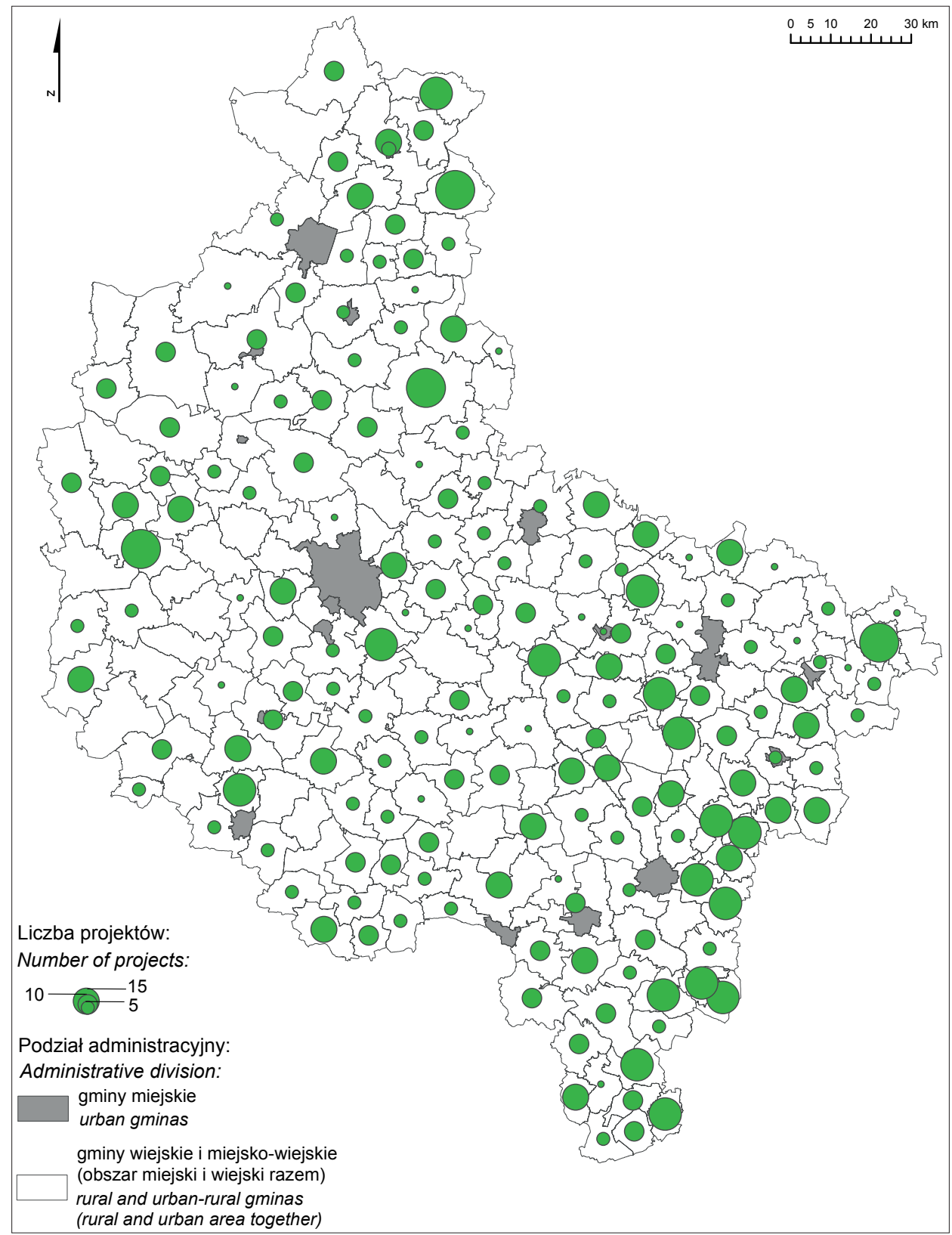

Ryc. 1. Liczba projektów zrealizowana przez społeczności lokalne uczestniczące w programie odnowy wsi w województwie wielkopolskim według gmin (opracowanie własne na podstawie danych Urzędu Marszałkowskiego Województwa Wielkopolskiego)

Fig. 1. Number of projects realised by local communities participating in the rural renewal programme in the Wielkopolskie Region by gminas (own work based on the data of the Marshal's Office of the Wielkopolskie Region) 


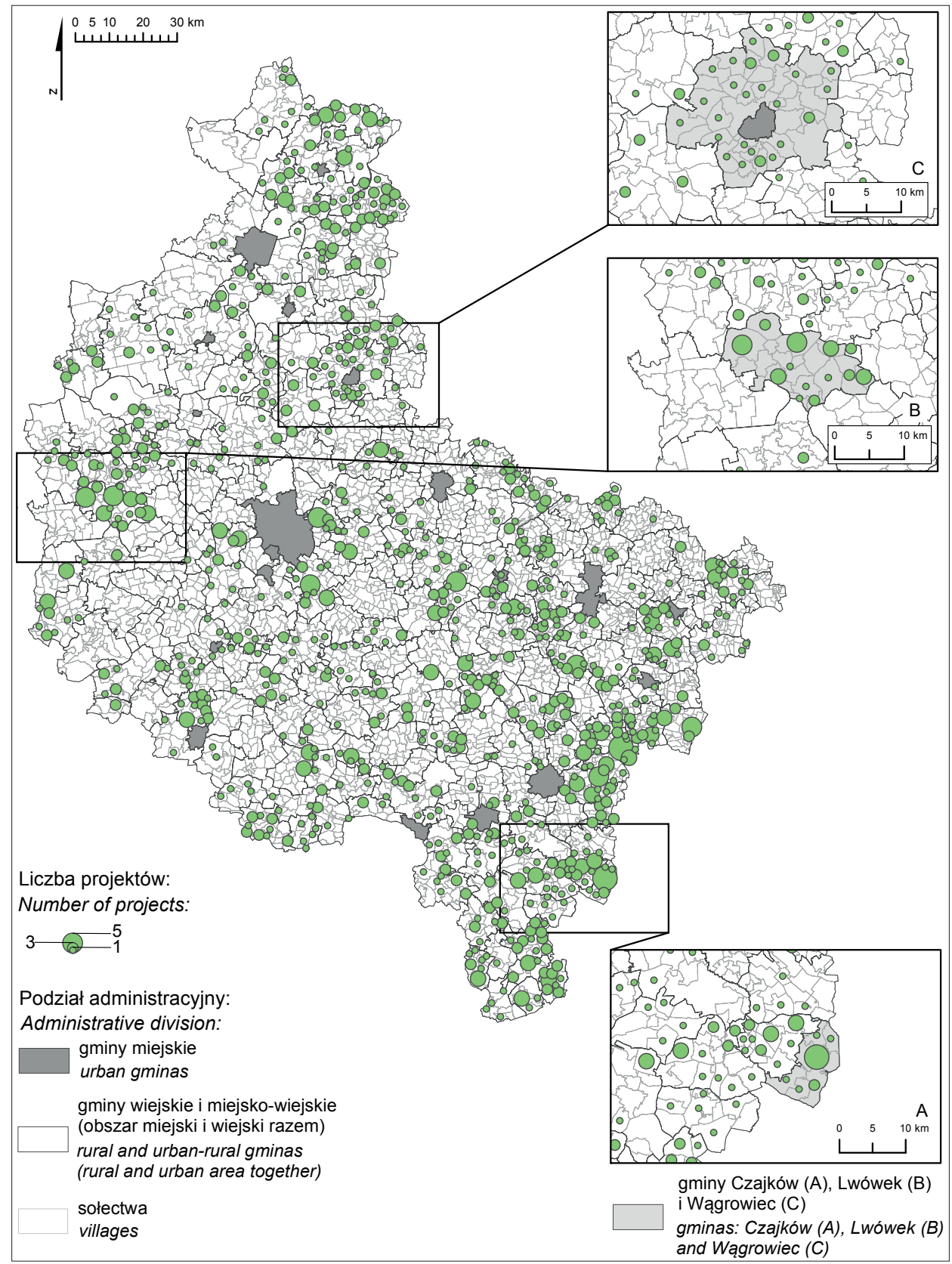

Ryc. 2. Liczba projektów zrealizowana przez społeczności wiejskie uczestniczące w programie odnowy wsi w województwie wielkopolskim według sołectw (opracowanie własne na podstawie danych Urzędu Marszałkowskiego Województwa Wielkopolskiego)

Fig. 2. Number of projects realised by rural communities participating in the rural renewal programme in the Wielkopolskie Region by villages (own work based on the data of the Marshal's Office of the Wielkopolskie Region) 
do niespełna 1/15. Jeśli te same dane analizować według 207 gmin, to w ponad 4/5 z nich społeczności były aktywne. Spośród nich 22 (13\%) były incydentalnie aktywne, a w 20 (11,9\%) zrealizowano więcej niż 15 projektów. Tym samym aktywność społeczności lokalnych, ale rozpatrywana w układach lokalnych (gminnych), wydawała się o wiele bardziej powszechna i w pewien sposób była „spłaszczona”.

Ostatnia z obserwacji dotyczy rozkładu przestrzennego projektów w obrębie pojedynczych gmin. Przykładowo na obszarze gminy Czajków społeczności wiejskie zrealizowały 18 projektów, z czego społeczność wsi Czajków zrealizowała 12 projektów, a pozostałe 6 projektów zrealizowały społeczności pięciu innych wsi (ryc. 2A). Na obszarze gminy Lwówek, gdzie zrealizowano największą liczbę projektów (39), społecznością najbardziej aktywną była ta zamieszkująca wieś Zębowo, która zrealizowała ,jedynie” 7 projektów. Społeczność jednej wsi zrealizowała 6 projektów, a społeczności dwóch wsi - po 5 projektów. Pozostałe 16 projektów zostało zrealizowanych przez społeczności siedmiu innych wsi (ryc. 2B). Wreszcie w gminie Wągrowiec, na obszarze której także zrealizowano dużą liczbę projektów (29), aktywnych było aż 24 społeczności (ryc. 2C). Przykłady te dowodzą, że można mówić o kilku typach rozkładu aktywności społeczności lokalnych w obrębie jednej gminy. W pierwszym przypadku można wyróżnić społeczność będącą zdecydowanym liderem aktywności w programie, której towarzyszą społeczności aktywne incydentalnie. W drugim przypadku raczej jest mowa o szerszym gronie najbardziej aktywnych społeczności, ale z pewnością nie tak liderujących. Towarzyszą im zarówno społeczności umiarkowanie aktywne, jak i te, które poprzestały na realizacji tylko jednego projektu. Natomiast w trzecim wypadku zdecydowana większość społeczności zrealizowała tylko po jednym projekcie. Choć praca nie miała na celu wyjaśnienia przyczyn takiego stanu rzeczy, to obserwacja dowiodła, że analizując aktywność społeczności lokalnej w programie według gmin, nie można wnioskować o wewnętrznej heterogeniczności tych obszarów.

\section{Rezultaty analizy hot spot aktywności społeczności lokalnych według gmin}

Kluczowa dla podjętego problemu badawczego była nie tylko dalsza eksploracja zagadnienia tworzenia się skupisk aktywnych społeczności, lecz także to, czy uzyskane rezultaty badań różnią się w zależności od przyjętej metody konceptualizacji relacji przestrzennych.

Na poziomie statystyki lokalnej, gdy wejściową klasą obiektów były gminy, analiza hot spot wykazała istnienie skupisk (klastrów), gdy metodą konceptualizacji relacji przestrzennych był zarówno odwrotny dystans (ryc. 3), jak i stały 


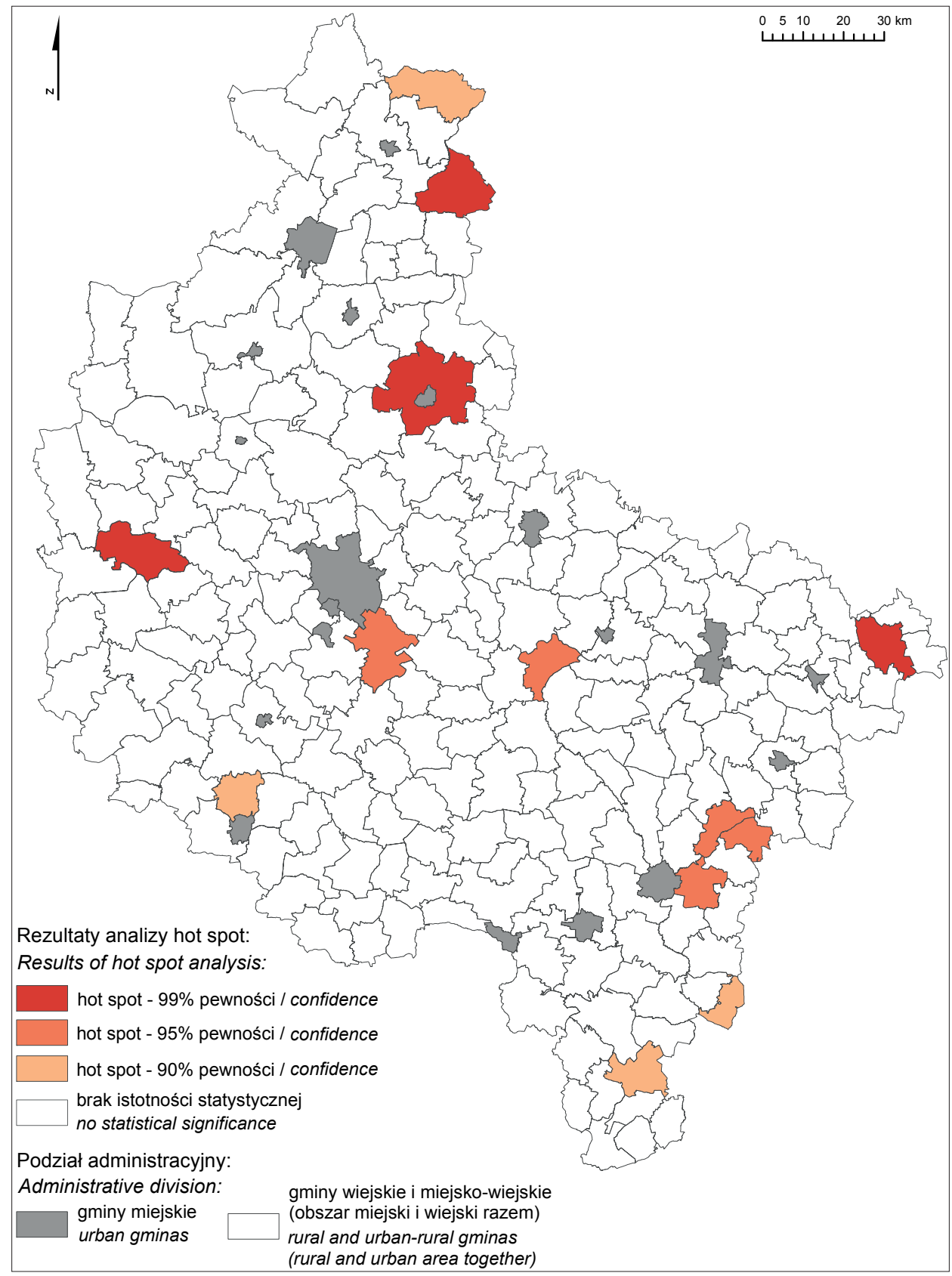

Ryc. 3. Rezultaty analizy hot spot aktywności społeczności lokalnych według gmin - odwrotny dystans (opracowanie własne)

Fig. 3. Results of the hot spot analysis for the activity of local communities computed by gminas - inverse distance (own work) 


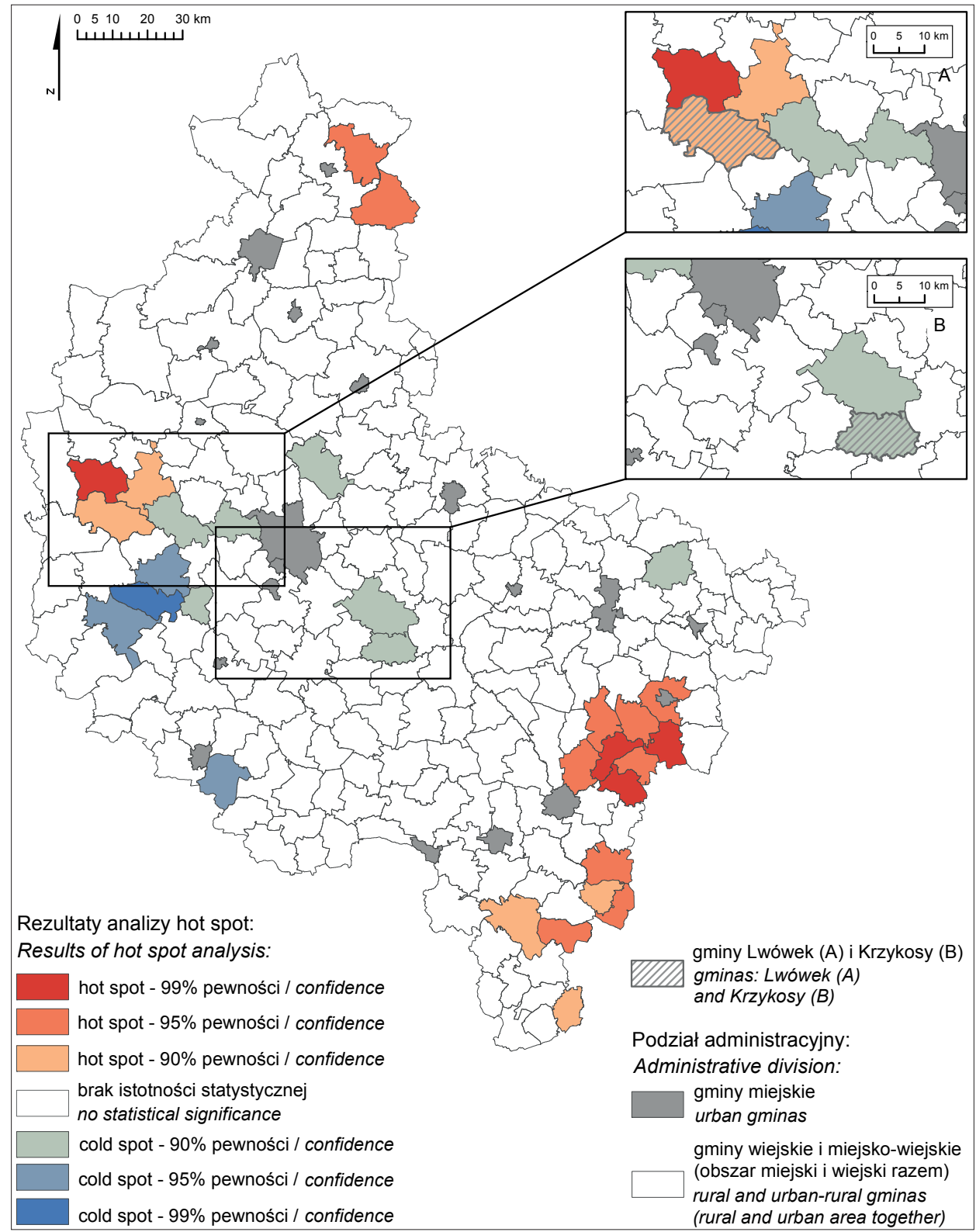

Ryc. 4. Rezultaty analizy hot spot aktywności społeczności lokalnych według gmin - stały dystans (opracowanie własne)

Fig. 4. Results of the hot spot analysis for the activity of local communities computed by gminas - fixed distance (own work) 
dystans (ryc. 4), przy czym w tym drugim przypadku skupisk było zdecydowanie więcej i obejmowały one skupiska hot i cold spotów.

Przy zastosowaniu odwrotnego dystansu analiza wskazała istnienie 13 hot spotów o różnym stopniu pewności, przy czym odpowiadał on liczbie zrealizowanych projektów, ponieważ hot spotami o 99-procentowym stopniu pewności były gminy, na obszarze których społeczności zrealizowały co najmniej 26 projektów, hot spotami o 95-procentowym stopniu pewności były gminy, gdzie zrealizowano co najmniej 20 projektów, a hot spotami o 90-procentowym stopniu pewności były gminy, w których zrealizowano co najmniej 18 projektów. Hot spoty nie tworzyły przy tym skupisk, z wyjątkiem jednego - w południowo-wschodniej części obszaru badań. Analiza nie zwróciła cold spotów (ryc. 3).

Na zdecydowanie bardziej mozaikowy charakter zjawiska wskazują rezultaty analizy hot spot, gdy metodą konceptualizacji relacji przestrzennych był stały dystans (ryc. 4), co dotyczy zarówno samego zaszeregowania obiektów do grupy hot i cold spotów, jak i tworzonych przez nie klastrów. Analiza wskazała na 30 hot i cold spotów, które w większości tworzyły z innymi hot lub cold spotami skupiska, przy czym dany klaster mógł składać się z hot lub cold spotów o różnym poziomie pewności. Hot spotów było 19, jednak liczba projektów zrealizowanych na obszarze danej gminy nie przełożyła się na ich stopień pewności. Przykładowo wspomniana wcześniej gmina Lwówek, na obszarze której zrealizowano 39 projektów, jest hot spotem, a uzyskała ,jedynie" 90-procentowy poziom pewności, podczas gdy sąsiadujące z nią gminy, mimo że zrealizowano na ich obszarze 12 i 11 projektów, były odpowiednio hot spotami z 99-procentowym i 90-procentowym poziomem pewności (por. ryc. $4 \mathrm{~A}$ z ryc. 1). Hot spoty utworzyły pięć klastrów, przy czym tylko dwa składały się z co najmniej trzech gmin. Klastry te znajdowały się w zachodniej, południowo-wschodniej oraz południowej części województwa.

Cold spotów było 11 (ryc. 4). Spośród 39 gmin, na obszarze których społeczności lokalne nie zrealizowały żadnego projektu, 9 stanowiło cold spoty. Interesujące jest to, że 2 cold spoty stanowiły gminy, na obszarze których zrealizowano projekty. Były to gminy: Krzykosy, gdzie zrealizowano 6 projektów (por. ryc. 4B z ryc. 1), oraz Rydzyna, gdzie zrealizowano 2 projekty. Cold spoty utworzyły jedno duże skupisko w zachodniej części województwa.

\section{Rezultaty analizy hot spot aktywności społeczności lokalnych według sołectw}

Przy zejściu na jeszcze bardziej lokalny poziom analizy, to znaczy gdy jej jednostką przestrzenną były sołectwa, otrzymano - w świetle wcześniej omówionych - spodziewane rezultaty. Wzrosła liczba hot i cold spotów (ryc. 5 i 6), przy 


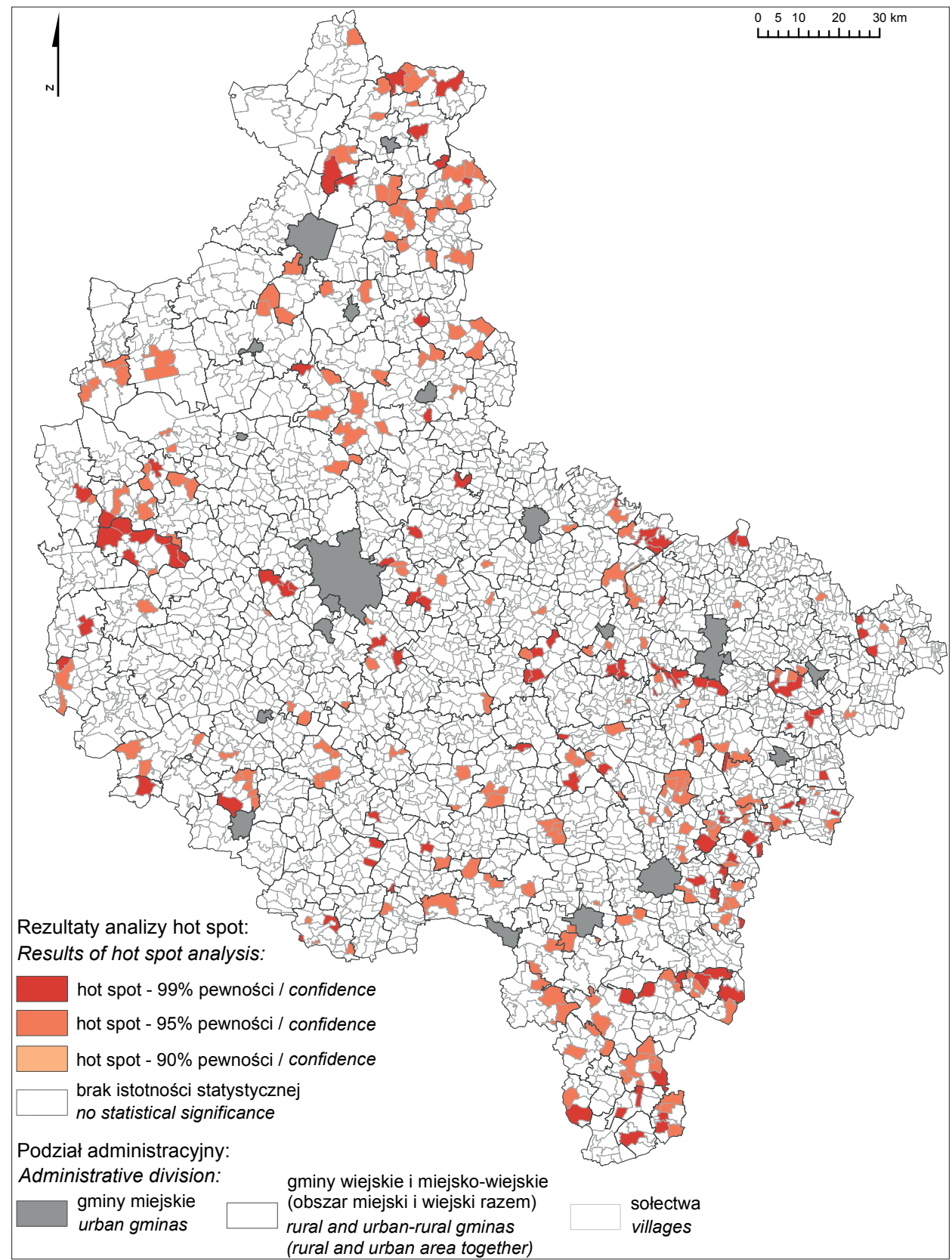

Ryc. 5. Rezultaty analizy hot spot aktywności społeczności lokalnych według sołectw - odwrotny dystans (opracowanie własne)

Fig. 5. Results of the hot spot analysis for the activity of local communities computed by villages - inverse distance (own work) 


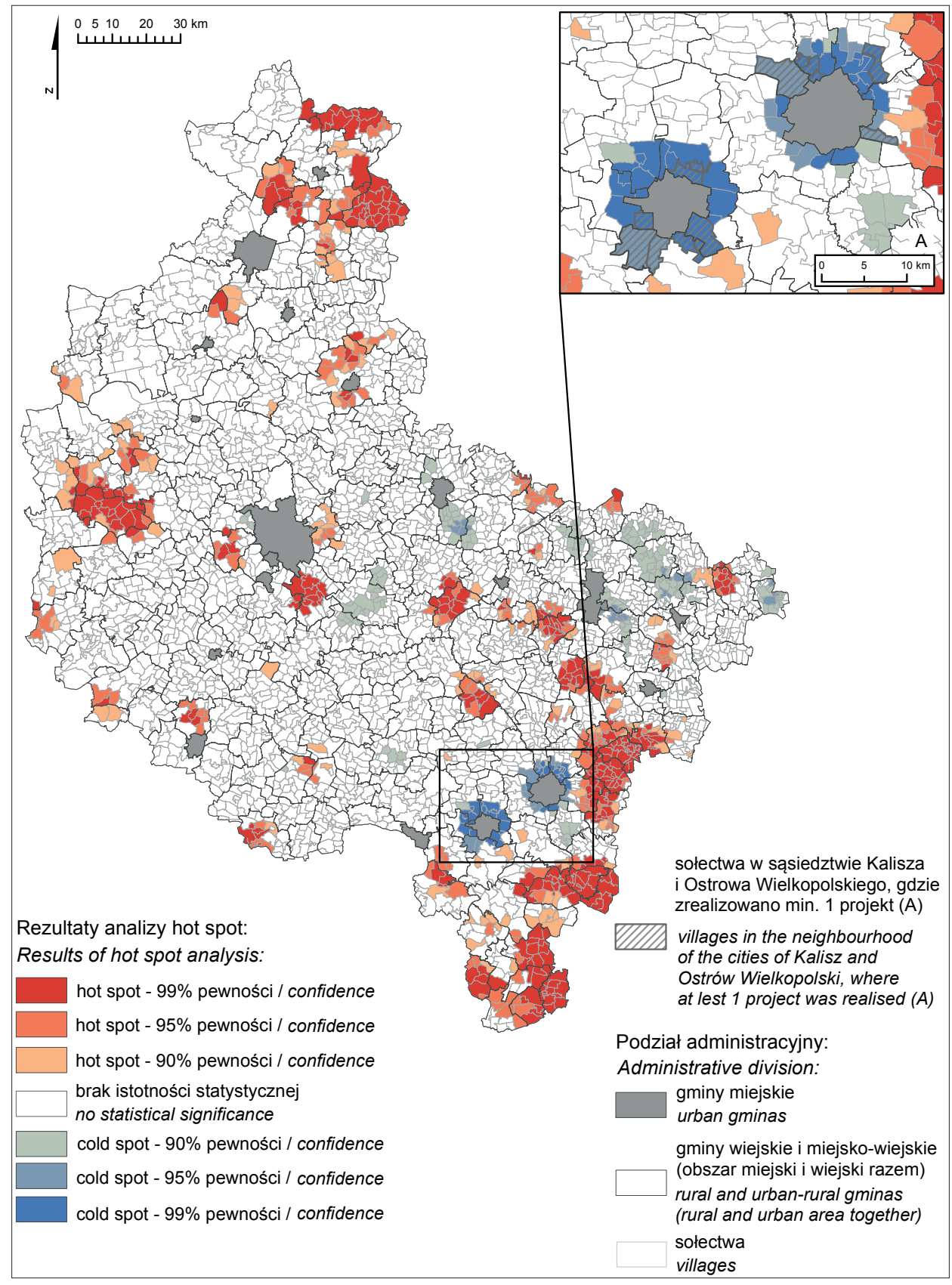

Ryc. 6. Rezultaty analizy hot spot aktywności społeczności lokalnych według sołectw - stały dystans (opracowanie własne)

Fig. 6. Results of the hot spot analysis for the activity of local communities computed by villages - fixed distance (own work) 
czym wzrost ten nie był rezultatem jedynie tego, że liczba jednostek przestrzennych analizy była większa (207 gmin wobec 4574 sołectw), lecz także wspomnianej wcześniej heterogeniczności układów lokalnych (gmin). Dowodzi tego istnienie hot i cold spotów na obszarach, na których ich nie zidentyfikowano, gdy to gminy były jednostkami przestrzennymi analizy (por. ryc. 3 z ryc. 5 oraz ryc. 4 z ryc. 6 ). Innymi słowy, jeżeli wcześniej wyróżniająca się aktywność (lub jej brak) pewnych społeczności lokalnych została niezauważona, to w tym wypadku stosowane narzędzia ją uchwyciły. W konsekwencji lokalizacja hot i cold spotów oraz ich skupisk „przecinała” również granice administracyjne gmin.

Jeśli chodzi o rezultaty analizy, gdy metodą konceptualizacji relacji przestrzennych był odwrotny dystans (ryc. 5), to ponownie nie zidentyfikowano cold spotów i liczba projektów zrealizowana przez społeczności zamieszkujące dane wsie miała bezpośrednie przełożenie na to, do jakiej kategorii hot spotów zaklasyfikowano te jednostki przestrzenne (hot spoty o 99-procentowym poziomie pewności stanowiły sołectwa, których mieszkańcy zrealizowali minimum 3 projekty, a hot spoty o 95-procentowym poziomie pewności sołectwa, gdzie zrealizowano 2 projekty). Społeczności, które zrealizowały 1 projekt, było tak wiele, że w analizie hot spot uznane zostały za nieistotne statystycznie (dlatego nie zidentyfikowano hot spotów o 90-procentowym poziomie pewności).

Biorąc pod uwagę liczbę hot spotów (303, co daje ponad 6\% ogółu wsi), liczba klastrów - sąsiadujących ze sobą bezpośrednio aktywnych wsi - jest relatywnie niewielka. Skupiska składające się z więcej niż trzech wsi zidentyfikowano głównie w północnej, zachodniej i południowej części obszaru badań. Skupiska składające się z mniejszej ich liczby były o wiele bardziej powszechne, jednak w ich lokalizacji nie ma prawidłowości.

Odnośnie do rezultatów ostatniego wariantu analizy hot spot (sołectwa jako wejściowa klasa obiektów i stały dystans jako metoda konceptualizacji relacji przestrzennych; ryc. 6) można zauważyć analogie do wcześniejszych rezultatów. Liczba wyróżnionych obiektów także wzrosła (627 hot spotów i 645 cold spotów) i ponownie ich zaszeregowanie do danej kategorii nie wynikało wprost z liczby projektów, jakie społeczności lokalne zrealizowały na obszarze tych sołectw. Właściwie każdy hot lub cold spot należał do skupiska składającego się z (wielu) podobnych do siebie obiektów. Samych klastrów było znacznie więcej niż w poprzednim przypadku. Największe skupiska hot spotów znów zlokalizowane były w północnej, zachodniej i południowej części województwa (a mniejsze dodatkowo w południowo-wschodniej i centralno-wschodniej jego części), natomiast cold spotów - w części wschodniej i południowo-wschodniej, gdzie otaczały często miasta. W związku z tym lokalizacja klastrów-sołectw nie odzwierciedla lokalizacji klastrów-gmin. 
Po raz kolejny doszło do zaklasyfikowania jednostek przestrzennych posiadających dodatni atrybut jako cold spoty (ogółem 16 sołectw, w których zrealizowano od 1 do 4 projektów). Niemal wszystkie takie cold spoty wystąpiły w sąsiedztwie Kalisza i Ostrowa Wielkopolskiego, gdzie odpowiednio w sześciu i ośmiu sołectwach zrealizowano projekty (por. ryc. 6A z ryc. 2). Podobnie 313 sołectw, gdzie nie zrealizowano ani jednego projektu, zostało zaklasyfikowanych jako hot spoty.

Na koniec warto wspomnieć, że obecność cold spotów lub ich brak to nie jedyna różnica w otrzymanych rezultatach między obiema dyskutowanymi metodami konceptualizacji relacji przestrzennych, niezależnie od tego, czy wejściową klasą obiektów były gminy czy sołectwa. Różnice te dotyczyły także lokalizacji hot spotów (por. ryc. $3 \mathrm{z}$ ryc. 4 oraz ryc. $5 \mathrm{z}$ ryc. 6). Mowa tutaj o dwóch przypadkach. W pierwszym pewne gminy-hot spoty lub sołectwa-hot spoty wyróżnione przy pierwszej z metod konceptualizacji były obiektami nieistotnymi statystycznie przy zmianie metody konceptualizacji na stały dystans. W drugim zaś wraz ze zmianą metody konceptualizacji zmienił się poziom pewności tych samych hot spotów.

\section{DYSKUSJA}

\section{Problemy kwantyfikacji zjawisk społecznych i doboru parametrów analizy}

W pracy zastosowano narzędzia GIS do eksploracji (zob. Griffiths 2011) wybranej cechy społeczności lokalnych uczestniczących w procesie rozwoju obszarów wiejskich. Choć celem nie było wyjaśnienie przyczyn tej aktywności (zróżnicowanej przestrzennie), rezultaty mogą być wykorzystane również do tego celu. Wynika to $\mathrm{z}$ faktu, że u podstaw przeprowadzonych analiz leżał proces geokodowania (nadania lokalizacji) uprzednio sprowadzonej do liczby zrealizowanych projektów aktywności społeczności (nadanie atrybutu poprzez kwantyfikację), co zapewniło istotność wyników (Heikkila 1998). Niniejsza część pracy poświęcona jest dyskusji tego, w jaki sposób można je wykorzystać w wyjaśnianiu aktywności społeczności lokalnych.

Sposób, w jaki dokonano kwantyfikacji tej aktywności, nie jest z pewnością doskonały i stanowi propozycję autora. Mówiąc o aktywności społeczności lokalnej, tak naprawdę należałoby mieć na względzie również jej działania nieformalne lub udział w konsultacjach działań realizowanych przez samorządy, ponieważ one też odgrywają istotną rolę w zarządzaniu rozwojem na poziomie lokalnym w Polsce (Goszczyński, Kamiński, Knieć, Woźniak 2013; Kołomycew, Pawłowska 2013). Jednakże analizy statystyczno-przestrzenne, w tym analizy 
klastrów, wymagają precyzyjnej definicji atrybutów, co jest problematyczne w przypadku zjawisk niemających swej bezpośredniej miary.

To właśnie w konieczności kwantyfikacji, obok specyfiki zastosowanych metod statystycznych, autor upatruje pewnych kontrowersji otrzymanych rezultatów. Dotyczą one tego, że: 1) hot spotami były gminy lub sołectwa, na terenie których społeczności nie były aktywne w programie odnowy wsi; 2) cold spoty występowały tam, gdzie społeczności były aktywne, i to powyżej średniej. Jako że analiza hot spot pod uwagę bierze przede wszystkim sąsiedztwo i naturalnie promuje tworzenie się skupisk (Mitchell 2005), należy przypuszczać, że z perspektywy statystyczno-przestrzennej są one istotniejsze niż wartość posiadanego przez obiekty atrybutu - stanowiącego wejściowe pole analizy. Dobrze ilustruje to zwłaszcza przypadek wspomnianych wcześniej gmin Krzykosy i Rydzyna oraz sołectw znajdujących się w bezpośrednim sąsiedztwie Kalisza i Ostrowa Wielkopolskiego, które są cold spotami pomimo faktu, że zamieszkujące je społeczności wiejskie zrealizowały projekty. Obie te gminy sąsiadują bezpośrednio z trzema innymi, w których nie zrealizowano żadnego projektu, a dodatkowo gmina Rydzyna sąsiaduje z miastem, na terenie którego programu odnowy wsi w ogóle nie realizowano. Podobnie rzecz ma się w przypadku wspomnianych sołectw, które także w dużej mierze sąsiadują z obszarami nieaktywnymi. Powyższe można odnieść też do lokalizacji hot spotów tam, gdzie nie zrealizowano żadnego projektu. Pomimo braku aktywności z perspektywy statystyczno-przestrzennej społeczności zamieszkujące te gminy lub sołectwa były predysponowane do uczestnictwa w programie, ponieważ otoczone były właśnie aktywnymi społecznościami. Można zatem powiedzieć, że aktywność lub brak aktywności na przytoczonych tutaj obszarach przeczą lokalnym prawidłowościom.

Istotna okazała się jeszcze metoda konceptualizacji relacji przestrzennych. W literaturze - w tym dotyczącej zjawisk, w których centralną rolę odgrywa człowiek - częściej stosuje się metodę stałego dystansu (Sánchez-Martín i in. 2019) i podobnie metodę tę faworyzuje środowisko ArcGIS, ponieważ metoda ta jest w nim domyślna (ESRI 2019). W świetle podjętego problemu i otrzymanych rezultatów wybór metody konceptualizacji nie jest jednak jednoznaczny. Stały dystans wyklucza wpływ obiektów znajdujących się poza określonym zakresem, co okazało się bardzo przydatne dla identyfikacji cold spotów. Nie ustalono jednak, jaki zakres jest odpowiedni dla określonych zjawisk. Zakres domyślny, zapewniający każdemu obiektowi co najmniej jednego sąsiada, wyniósł 16397 m / 5928 m, lecz trudno stwierdzić, że na aktywność społeczną w danej gminie czy wsi wpływa aktywność społeczna w gminach czy wsiach oddalonych o tę odległość, ale już nie w tych oddalonych o odległość o jeden metr większą, co w gruncie rzeczy zakłada ta metoda konceptualizacji relacji przestrzennych. 
Z kolei metoda odwrotnego dystansu przyjmuje, że każdy obiekt jest sąsiadem każdego innego obiektu. Zdaniem autora $\mathrm{z}$ pewnymi zastrzeżeniami może być ona pomocna, gdy mowa o bardziej abstrakcyjnych koncepcjach, takich jak bliskość poznawcza, gdzie odległość fizyczna nie odgrywa aż tak dużej roli. Gminy lub wsie, które są od siebie oddalone, mogą wywierać na siebie większy wpływ w kontekście aktywności w programie niż te, które są blisko siebie, ponieważ wszystkie społeczności biorące udział w programie w pewien sposób ze sobą rywalizują, choćby o miano tej najbardziej aktywnej, za co operator programu odnowy wsi w województwie wielkopolskim przyznawał nagrody (Wielkopolska Odnowa Wsi 2013-2020). Jednakże przy braku ujemnych wartości wejściowego pola analizy (czyli braku ujemnej liczby zrealizowanych przez społeczności projektów) rozkład zjawiska daleki jest od normalnego. Wartością skrajną jest „,", przy czym w dyskutowanym przypadku liczba obiektów posiadających skrajną wartość atrybutu nie maleje, co może thumaczyć, dlaczego nie otrzymano cold spotów.

Kolejnym stwierdzonym ograniczeniem odwrotnego dystansu jest fakt, że rezultaty analizy hot spot bardzo silnie korespondowały z ,surowymi” danymi na temat liczby zrealizowanych przez społeczności projektów, ponieważ im większa ona była, tym większy stopień pewności uzyskiwały poszczególne hot spoty. Na tej podstawie można stwierdzić, że analiza hot spot przy tej metodzie konceptualizacji pozwoliła jedynie na znalezienie takiej wartości atrybutu, która pozwala zakwalifikować obiekt jako hot spot o danym stopniu pewności.

„Uwzględnienie aspektu przestrzennego w naukach społecznych jest istotne, ponieważ aktywności społeczne i relacje międzyludzkie zawsze mają miejsce w czasie i przestrzeni" (Griffiths 2011, s. 433). Z tego powodu symbolizacja i odwzorowanie danych nie są wystarczające - zapewniają możliwość analizy, ale bez zastosowania odpowiednio opisanych narzędzi, które zapewniają także powtarzalność procedur, rezultaty tej analizy pozostają w dużej mierze zależne od interpretacji autorów. Zastosowane narzędzia GIS dostarczyły nowego spojrzenia na zjawisko dobrowolnej aktywności społeczności wiejskich w rozwoju obszarów wiejskich, jednakże z uwagi na swoją specyfikę ich zastosowanie wymaga udoskonalenia. Dotyczy to przede wszystkim metod kwantyfikacji informacji na temat aktywności społeczności lokalnych oraz optymalizacji parametrów samej analizy hot spot, a zwłaszcza wyboru metody konceptualizacji relacji przestrzennych między obiektami.

\section{Implikacje dla badań rozwoju obszarów wiejskich}

Jak wspomniano w pierwszej części dyskusji, niniejsze badanie daje podstawy do wyjaśnienia przyczyn aktywności społeczności lokalnych w wybranych 
programach rozwoju obszarów wiejskich, które zapewniają możliwość uczestnictwa i kreowania otaczającego społeczności środowiska. Jeśli chodzi o społeczną interpretację zjawisk, które badano za pomocą podobnych metod statystyczno-przestrzennych, należy wyróżnić przede wszystkim teorię zachowań rutynowych. Natomiast w kontekście tworzenia się powiązań między obszarami wiejskimi na uwagę zasługuje teoria sieci.

Teoria zachowań rutynowych rozpowszechniła się w badaniach nad zjawiskami uznawanymi społecznie za negatywne, zwłaszcza takimi jak przestępczość (zob. Anselin i in. 2000; Mordwa 2013; Miró 2014). Zgodnie z nią - w bardzo dużym uproszczeniu - poza określonymi warunkami sprzyjającymi popełnieniu czynu zachowania mają miejsce w następstwie sobie podobnych, które wydarzyły się w przeszłości i często zachodzą w lokalizacjach sąsiednich (Felson, Cohen 1980). Stąd wysuwa się wniosek, że miejsca, w których już raz doszło do incydentu są bardziej predysponowane do tego, by do podobnego incydentu doszło ponownie. Taki sposób rozumowania można zastosować także w przypadku aktywności społeczności lokalnych na polu realizacji dobrowolnych - gdzie przymiotnik ten jest kluczowy - działań na rzecz danego miejsca i w nim. W odpowiednich warunkach (środowiskowych i instytucjonalnych) realizacja działań spajających społeczności i prowadzących je do wspólnego celu napędza realizację działań kolejnych (Kłodziński 2006). Biorąc jednak pod uwagę otrzymane rezultaty, należy dodać, że ma to miejsce tylko po przekroczeniu pewnej „masy krytycznej”, to znaczy określonej liczby projektów. Tę liczbę projektów być może udało się zidentyfikować w następstwie analizy hot spot, gdy metodą konceptualizacji relacji przestrzennych był odwrotny dystans. Hot spoty stanowiły te miejsca, gdzie aktywność była wystarczająco duża, aby stała się rutynowa. Podobnej mocy sprawczej nie ma przy tym incydentalna aktywność społeczności lokalnych, zresztą wysoki odsetek takich społeczności to potwierdza - gdyby działały rutynowo, zrealizowałyby większą liczbę projektów. Jednakże tylko społeczności posiadające określoną strategię realizują projekty, rok po roku (lub częściej) aplikując o środki finansowe.

$\mathrm{Na}$ poziomie lokalnym praktyki są ze sobą na tyle powiązane (van der Ploeg i in. 2015), że trudno określić, na ile pewne są związki przyczynowo-skutkowe między aktywnością społeczności lokalnych a cechami środowiska i innymi zjawiskami społeczno-gospodarczymi obserwowanymi w przestrzeni. Jednak wiedząc, że społeczności te tworzą skupienia i zakładając, że zjawisko tworzenia się skupień jest pozytywne, można prowadzić polityki mające na celu promocję zachowań spajających społeczności (por. Andersson, Serger, Sörvik, Hansson 2004). Badania dowodzą, że obecność w klastrze sprzyja chociażby przepływom wiedzy i kapitału oraz wymianie doświadczeń (np. Faulconbridge 
2009), ponieważ relacje pomiędzy aktorami i procesami są ważniejsze niż pojedyncze aktywności (Ventura, Brunori, Milone, Berti 2008). Również w programach odnowy wsi, o czym wspomniano przy okazji rozważań teoretycznych, wzmacnianie tych cech odgrywa istotną rolę.

W związku z tym klastry można pojmować jako specyficzną formę sieci, w której aktorzy powiązani są ze sobą na podstawie wspólnej, decydującej cechy. Współcześnie w studiach wiejskich pojęcie „sieci” (networks lub webs) jest wykorzystywane dosyć powszechnie (Murdoch 2000). Z jednej strony obszary wiejskie stanowią część przeplatających się ze sobą sieci społeczno-technologicznych, politycznych i gospodarczych, które tworzą pewne trwałe struktury (Murdoch 2006). Z drugiej zaś zainteresowanie sieciami skupia uwagę - zarówno jeśli chodzi o dociekania teoretyczne, jak i badania empiryczne - w większym stopniu na samych relacjach niż na przedmiocie tych relacji (Fuchs 2001). Jako że sieci, o jakich tutaj mowa, należy rozumieć jako społeczności o wspólnych interesach i dzielące wspólne praktyki (Wiskerke, van der Ploeg 2004), to ich istnienie nie wymaga kontaktu bezpośredniego czy osobistego. Warunkiem istnienia takich sieci są za to wspólne dla nich mapy wyobrażeniowe (cognitive maps) (Ventura i in. 2008; zob. także Kitchin 1994; Ungar 2005).

Powyższe ma zastosowanie $\mathrm{w}$ interpretacji rezultatów przeprowadzonych badań na dwu płaszczyznach. Po pierwsze, testowano dwie różne metody konceptualizacji relacji przestrzennych, a tym samym swoiste zasięgi oddziaływania sieci i elementów je budujących na siebie. Zwłaszcza zastosowanie odwrotnego dystansu, zakładającego wpływ obiektów na siebie niezależnie od odległości, przywodzi na myśl wspomniane mapy wyobrażeniowe, gdzie odległość fizyczna nie ma już tak dużego znaczenia. Po drugie, rezultaty wskazują, że tego typu sieci nie tylko mogą być niedostrzegalne w układach gminnych, lecz także tworzą się niezależnie od przebiegu ich granic. Tym samym można mówić raczej o lokalnych obszarach aktywności, czyli powiązanych ze sobą wsiach zamieszkiwanych przez społeczności aktywnie uczestniczące w programie odnowy wsi, dla których istnienia istotniejszy jest wspólny sposób myślenia, a nie przynależność do danej jednostki administracyjnej.

Z perspektywy dalszych badań bardzo interesujące jest to, czy również inne praktyki rozwoju obszarów wiejskich na poziomie lokalnym mogą wykazywać tendencję do skupiania, a tym samym być ujęte w sieci oraz czy interpretacje tych praktyk różnią się w zależności od przyjętej jednostki przestrzennej analizy. Jeśli tak, dałoby to przyczynek ku dalszym rozważaniom, czy współcześnie nie należy kreować rozwoju w taki sposób, aby w większym stopniu odpowiadał on na potrzeby wsi, a nie obszarów wiejskich (gmin). Dzięki zastosowanym narzędziom przeprowadzenie podobnych badań możliwe jest także w innych obszarach 
i ,miejscach”, co otwiera furtkę dla dalszych badań porównawczych, a mimo to wciąż skoncentrowanych na praktykach zachodzących na szczeblu lokalnym.

\section{WNIOSKI}

Pomimo faktu, że praca traktowała tylko o jednym elemencie polityki rozwoju obszarów wiejskich, realizowanym w jednym regionie, to z uwagi na cechy zjawisk społecznych zachodzących w przestrzeni (wiejskiej), współczesne dylematy kształtowania polityk rozwoju obszarów wiejskich oraz dyskusję na temat zagadnień teoretyczno-metodologicznych w studiach wiejskich ma ona dosyć złożony charakter, co odzwierciedlają jej cele.

Co do głównego celu opracowania, pozytywnie zweryfikowano, że aktywność społeczności lokalnych jest praktyką specyficzną na poziomie poszczególnych wsi, a to oznacza, że jej interpretacja może być inna w przypadku, gdy jednostką przestrzenną analizy jest obszar wiejski - gmina. Społeczności aktywne w programie odnowy wsi tworzą skupiska, które stanowią specyficzną formę sieci, a ich istnienie jest niezależne od przebiegu granic administracyjnych. Na aktywność tę - w świetle zastosowanych narzędzi - wpływają jednocześnie efekt sąsiedztwa i bliskość poznawcza.

Programy odnowy wsi różnią się znacząco od programów finansowanych ze środków Unii Europejskiej. W tych drugich podstawową jednostką działań jest najczęściej obszar wiejski i to właśnie jego cechy społeczno-gospodarcze są brane pod uwagę przy programowaniu. W programach odnowy wsi tymi jednostkami są sołectwa, a o powodzeniu w realizacji tych programów decyduje dobrowolna aktywność społeczności je zamieszkujących. Biorąc pod uwagę, że programy wspierane przez polityki unijne są częściej eksplorowanym zagadnieniem badawczym, praca ujawniła specyficzne cechy procesu rozwoju obszarów wiejskich realizowanego poza „mainstreamem”, do których - oprócz wcześniej wymienionych - należy heterogeniczność obszarów wiejskich na poziomie lokalnym. Rezultaty pracy mogą zostać wykorzystane do wyjaśnienia przyczyn aktywności społeczności lokalnych, a kolejne badania z pogranicza studiów wiejskich i statystyki przestrzennej mogą przybliżyć środowisko naukowe i decydentów do odpowiedzi na pytanie, czy potrzebne są zmiany w metodologii programowania rozwoju obszarów wiejskich, tak jak sugerują to współczesne koncepcje rozwoju obszarów wiejskich.

Powtarzalność stosowanych procedur badawczych jest istotnym celem samym w sobie w kontekście budowania programu badawczego studiów nad rozwojem obszarów wiejskich, ponieważ pozwala na porównywanie zjawisk w różnych obszarach. Na przykładzie przeprowadzonych badań można stwierdzić, że aby 
narzędzia GIS służące analizie klastrów mogły być w tym celu powszechnie wykorzystywane, należy udoskonalić takie kwestie, jak kwantyfikacja zjawisk społecznych i dobór parametrów samych analiz.

Źródla finansowania: Autor uzyskał środki finansowe w ramach finansowania stypendium doktorskiego z Narodowego Centrum Nauki, numer rejestracyjny: 2019/32/T/HS4/00194.

\section{BIBLIOGRAFIA}

\section{Literatura}

Andersson T., Serger S.S., Sörvik J., Hansson E.W. 2004. The Cluster Policies Whitebook. International Organisation for Knowledge Economy and Enterprise Development.

Anselin L., Cohen J., Cook D., Gorr W., Tita G. 2000. Spatial analyses of crime. W: D. Duffee (ed.), Measurement and Analysis of Crime and Justice (s. 213-262). Rockville: NCJRS.

Babbie E. 2004. Badania społeczne w praktyce. Warszawa: Wydawnictwo Naukowe PWN.

Baldock D., Dwyer J., Lowe P., Petersen J.E., Ward N. 2001. The Nature of Rural Development: Towards a Sustainable Integrated Rural Policy in Europe. London: Institute for European Environmental Policy.

Bivand R. 1980. Autokorelacja przestrzenna a metody analizy statystycznej w geografii. W: Z. Chojnicki (red.), Analiza regresji w geografi (s. 23-38). Poznań: PWN.

Boschma R.A. 2005. Proximity and Innovation: A Critical Assessment. Regional Studies 39(1), 61-74. https://doi.org/10.1080/0034340052000320887

Brennan M.A., Flint C.G., Luloff A.E. 2009. Bringing Together Local Culture and Rural Development: Findings from Ireland, Pennsylvania and Alaska. Sociologia Ruralis 49(1), 97-112. https://doi.org/10.1111/j.1467-9523.2008.00471.x

Chigbu U.E. 2012. Village renewal as an instrument of rural development: evidence from Weyarn, Germany. Community Development 43(2), 209-224. https://doi.org/10.1080/15575330.2011.575231

Deakin R.E., Bird S.C., Grenfell R.I. 2002. The Centroid? Where would you like it to be be? Cartography 31(2), 153-167. https://doi.org/10.1080/00690805.2002.9714213

Dmochowska-Dudek K., Bednarek-Szczepańska M. 2018. A profile of the Polish rural NIMBYist. Journal of Rural Studies 58, 52-66. https://doi.org/10.1016/j.jrurstud.2017.12.025

Ellis F., Biggs S. 2001. Evolving Themes in Rural Development 1950s-2000s. Development Policy Review 19(4), 437-448. https://doi.org/10.1111/1467-7679.00143

Erden H., Kaya I.A., Öcal M. 2015. Rural development studies and geographical information systems. Istanbul: 2015 Fourth International Conference on Agro-Geoinformatics. https://doi. org/10.1109/Agro-Geoinformatics.2015.7248097

European Network for Rural Development, 2018. Smart Villages. Revitalising Rural Services. EU Rural Review, 26. Luxembourg: Publications Office of the European Union.

Faulconbridge J. 2009. Clusters. W: D. Gregory, R. Johnston, G. Pratt, M.J. Watts, S. Whatmore (eds.), The Dictionary of Human Geography (s. 91-92). Chichester: Wiley-Blackwell.

Felson M., Cohen L.E. 1980. Human ecology and crime: A routine activity approach. Human Ecology 8(4), 389-405. https://doi.org/10.1007/BF01561001 
Flyn A., Marsden T.K. 1995. Guest editorial. Environment and Planning A: Economy and Space 27(8), 1180-1192. https://doi.org/10.1068/a271180

Fuchs S. 2001. Against Essentialism. A Theory of Culture and Society. Harvard: Harvard University Press. https://doi.org/10.4159/9780674037410

Furmankiewicz M., Thompson N., Zielińska M. 2010. Area-based partnerships in rural Poland: The post-accession experience. Journal of Rural Studies 26(1), 52-62. https://doi.org/10.1016/j. jrurstud.2009.05.001

Getis A., Ord J.K. 1992. The analysis of spatial association by use of distance statistics. Geographical Analysis 24(3), 189-206. https://doi.org/10.1111/j.1538-4632.1992.tb00261.x

Goodchild M.F., Haining R.P., Wise S. 1992. Integrating GIS and spatial analysis: problems and possibilities. International Journal of Geographical Information Systems 6(5), 407-423. https://doi.org/10.1080/02693799208901923

Griffiths E. 2011. Geographic Information Systems (GIS) and spatial analysis. W: M. Williams, W.P. Vogt (eds.), The SAGE Handbook of Innovation in Social Research and Methods (s. 442-464). London: SAGE. https://doi.org/10.4135/9781446268261.n25

Halfacree K. 2006. Rural space: Constructing a three-fold architecture. W: P. Cloke, T. Marsden, P. Mooney (eds.), Handbook of Rural Studies (s. 44-62). London: SAGE. https://doi. org/10.4135/9781848608016.n4

Heikkila E. 1998. GIS is Dead; Long Live GIS! Journal of the American Planning Association 64(3), 350-360. https://doi.org/10.1080/01944369808975991

Hodge I., Midmore P. 2008. Models of Rural Development and Approaches To Analysis Evaluation And Decision-Making. Économie rurale 307, 23-38. https://doi.org/10.4000/economierurale.406

Hoggart K., Black R., Buller H. 1995. Rural Europe. Identity and Change. London: Routledge.

Huttner N. 2013. Entwicklung ländlicher Kommunen. Wenn Bürger Beteiligung ernst nehmen. Organisationsberatung, Supervision, Coaching 20, 23-34. https://doi.org/10.1007/s11613-0130309-1

Idziak W., Wilczyński R. 2013. Odnowa wsi. Przestrzeń, ludzie, działania. Warszawa: Fundacja Programów Pomocy dla Rolnictwa FAPA.

Ilbery B. (ed.). 1998. The Geography of Rural Change. London: Pearson Education Limited.

Kitchin R.M. 1994. Cognitive maps: What are they and why study them? Journal of Environmental Psychology 14(1), 1-19. https://doi.org/10.1016/S0272-4944(05)80194-X

Kłodziński M. 2006. Aktywizacja społeczno-gospodarcza gmin wiejskich i małych miast. Warszawa: Instytut Rozwoju Wsi i Rolnictwa PAN.

Knickel K., Renting H. 2000. Methodological and Conceptual Issues in the Study of Multifunctionality and Rural Development. Sociologia Ruralis 40(4), 512-528. https://doi.org/10.1111/14679523.00164

Knievel M. 1997. Neue Länder - Neue Wege? Geistige Dorfentwicklung in Sachsen: Anspruch und Wirklichkeit. Münchener Geographische Hefte 75, 9-28.

Kołomycew A., Pawłowska A. 2013. Partnerstwa międzysektorowe w rozwoju obszarów wiejskich na przykładzie lokalnych grup działania w województwie podkarpackim. Studia Regionalne i Lokalne 2(25), 62-80. 
Magel H. 2000. Village renewal - model for self-initiative and future orientation. Zeitschrift für Kulturtechnik und Landentwicklung 41(6), 274-278.

McArdle K. 2012. What makes a successful rural regeneration partnership? The views of successful partners and the importance of ethos for the community development professional. Сommunity Development 43(3), 333-345. https://doi.org/10.1080/15575330.2011.621211

McAreavey R. 2006. Getting Close to the Action: The Micro-Politics of Rural Development. Sociologia Ruralis 46(2), 85-103. https://doi.org/10.1111/j.1467-9523.2006.00407.x

Michałowska E. 2008. Syndrom NIMBY jako przykład samoorganizacji społecznej na poziomie lokalnym. Studia Regionalne i Lokalne 1(38), 60-80.

Mitchell A. 2005. The ESRI Guide to GIS Analysis (Vol. 2). Redlands: ESRI Press.

Mordwa S. 2013. Zastosowanie GIS w badaniach przestępczości. Acta Universitatis Lodziensis. Folia Geographica Socio-Oeconomica (14), 77-92.

Morris A. 1998. Geography and Development. London: UCL Press.

Moseley M. 2003. Rural Development: Principles and Practice. London: SAGE.

Murdoch J. 2000. Networks - a new paradigm of rural development? Journal of Rural Studies 16(4), 407-419. https://doi.org/10.1016/S0743-0167(00)00022-X

Murdoch J. 2006. Post-structuralist Geography. A Guide to Relational Space. London: SAGE.

Murray M., Dunn L. 1995. Capacity building for rural development in the United States. Journal of Rural Studies 11(1), 89-97. https://doi.org/10.1016/0743-0167(94)00056-F

Naldi L., Nilsson P., Westlund H., Wixe S. 2015. What is smart rural development? Journal of Rural Studies 40, 90-101. https://doi.org/10.1016/j.jrurstud.2015.06.006

Nooteboom B. 2000. Learning and Innovation in Organizations and Economies. Oxford: Oxford University Press. https://doi.org/10.1093/acprof:oso/9780199241002.001.0001

OECD, 2006. The New Rural Paradigm: Policies and Governance. Paris.

Pałka-Łebek E., Brambert P. 2018. Innowacyjność w gospodarstwach agroturystycznych. Acta Universitatis Lodziensis. Folia Geographica Socio-Oeconomica (32), 125-138. https://doi. org/10.18778/1508-1117.32.07

Pieczonka J. 2018. Aktywność sołectw wspierających rozwój społeczny w ramach Programu Odnowy Wsi w latach 2013-2015. Studia Obszarów Wiejskich 52, 63-75. https://doi.org/10.7163/ SOW.52.5

Ploeg J.D. van der, Renting H. 2000. Impact and Potential: A Comparative Review of European Rural Development Practices. Sociologia Ruralis 40(4), 529-543. https://doi.org/10.1111/14679523.00165

Ploeg J.D. van der, Renting H., Brunori G., Knickel K., Mannion J., ..., Ventura F. 2000. Rural Development: From Practices and Policies towards Theory. Sociologia Ruralis 40(4), 391-408. https://doi.org/10.1111/1467-9523.00156

Ploeg J.D. van der, Ye J., Schneider S. 2015. Rural Development: Actors and Practices. W: P. Milone, F. Vantura, J. Ye (eds.), Constructing a New Framework for Rural Development (s. 17-30). Bingley: Emerald Publishing. https://doi.org/10.1108/S1057-192220150000022001

Ray Ch. 2000. Endogenous socio-economic development in the European Union? Issues of evaluation. Journal of Rural Studies 16(4), 447-458. https://doi.org/10.1016/S0743-0167(00)00012-7 
Rice S. 2010. Sampling in geography. W: N. Clifford, S. French, G. Valentine (eds.), Key Methods in Geography (s. 230-252). London: SAGE.

Rosner A., Stanny M. 2014. Monitoring rozwoju obszarów wiejskich. Etap I: Przestrzenne zróżnicowanie poziomu rozwoju społeczno-gospodarczego obszarów wiejskich w 2010 roku. Warszawa: Fundacja Europejski Fundusz Rozwoju Wsi Polskiej, Instytut Rozwoju Wsi i Rolnictwa PAN.

Sánchez-Martín J.M., Rengifo-Gallego J.I., Blas-Morato R. 2019. Hot Spot Analysis versus Cluster and Outlier Analysis: An Enquiry into the Grouping of Rural Accommodation in Extremadura (Spain). International Journal of Geoinformation 8(4), 176-203. https://doi.org/10.3390/ ijgi8040176

Scott L.M., Janikas M.V. 2009. Spatial Statistics in ArcGIS. W: M.M. Fischer, A. Getis (eds.), Handbook of Applied Spatial Analysis (s. 27-41). Berlin: Springer-Verlag. https://doi. org/10.1007/978-3-642-03647-7_2

Shortall S. 2008. Are rural development programmes socially inclusive? Social inclusion, civic engagement, participation, and social capital: Exploring the differences. Journal of Rural Studies 24(4), 450-457. https://doi.org/10.1016/j.jrurstud.2008.01.001

Stanny M. 2013. Zasoby lokalne jako czynniki rozwoju obszarów wiejskich w Polsce. W: M. Stanny (red.), Przestrzenne zróżnicowanie rozwoju obszarów wiejskich w Polsce (s. 213-262). Warszawa: Instytut Rozwoju Wsi i Rolnictwa PAN.

Storey D. 1999. Issues of Integration, Participation and Empowerment in Rural Development: The Case of LEADER in the Republic of Ireland. Journal of Rural Studies 15(3), 307-315. https:// doi.org/10.1016/S0743-0167(98)00073-4

Terluin I.J. 2003. Differences in economic development in rural regions of advanced countries: An overview and critical analysis of theories. Journal of Rural Studies 19(3), 327-344. https://doi.org/10.1016/S0743-0167(02)00071-2

Ungar S. 2005. Cognitive maps. W: R.W. Caves (ed.), Encyclopedia of the City (s. 79). London: Routledge.

Ventura F., Brunori G., Milone P., Berti G. 2008. The rural web: A synthesis. W: J.D. van der Ploeg, T. Marsden (eds.), Unfolding Webs: The Dynamics of Regional Rural Development (s. 149174). Assen: Van Gorcum.

Visvizi A., Lytras M. 2018. Rescaling and refocusing smart cities research: from mega cities to smart villages. Journal of Science and Technology Policy Management 9(2), 134-145. https://doi. org/10.1108/JSTPM-02-2018-0020

Wielkopolska Odnowa Wsi 2013-2020. Załącznik do uchwały nr IV/88/2015 Sejmiku Województwa Wielkopolskiego z dnia 23 lutego 2015 roku. Urząd Marszałkowski Województwa Wielkopolskiego, Departament Rolnictwa i Rozwoju Wsi.

Wieruszewska M. 1992. Wstęp. W: M. Wieruszewska (red.), Odnowa wsi. Między mitem a nadzieja (s. 158-177). Warszawa: Instytut Rozwoju Wsi i Rolnictwa Polskiej Akademii Nauk.

Wilczyński R. 2003. Odnowa wsi perspektywa rozwoju obszarów wiejskich w Polsce. Poznań: Fundacja Fundusz Współpracy - Program Agro-Info, Krajowe Centrum Doradztwa Rozwoju Rolnictwa i Obszarów Wiejskich Oddział w Poznaniu.

Wilson O.J. 1999. Village renewal and rural development in the former German Democratic Republic. GeoJournal 46, 247-255. 
Wiskerke J.S.C., Ploeg J.D. van der 2004. Seeds of Transition: Essays on Novelty Production, Niches and Regimes in Agriculture. Assen: Van Gorcum.

Wolski O. 2017. Specyfika wojewódzkich programów odnowy wsi w Polsce w kontekście literatury naukowej dotyczącej odnowy. Studia Obszarów Wiejskich 48, 51-73.

Wolski O., Wójcik M. 2019. Smart Villages Revisited: Conceptual Background and New Challenges at the Local Level. W: A. Visvizi, M.D. Lytras., G. Mudri (eds.), Smart Villages in the EU and Beyond (s. 29-48). Bingley: Emerald Publishing. https://doi.org/10.1108/978-1-78769845-120191004

Woods M. 2005. Rural Geography: Processes, Responses and Experiences in Rural Restructuring. London: SAGE.

Woods M. 2009. Rural Geography. W: R. Kitchin, N. Thrift (eds.), International Encyclopedia of Human Geography (s. 429-441). Amsterdam-Oxford: Elsevier. https://doi.org/10.1016/ B978-008044910-4.00900-7

Wójcik M. 2014. Obszary versus miejsca, czyli o przestrzennych formach interpretacji przemian polskiej wsi. Studia Obszarów Wiejskich 34, 9-22.

Wójcik M., Czapiewski K., Jeziorska-Biel P. 2019. Between words: A generational discussion about farming knowledge sources. Journal of Rural Studies 67, 130-141. https://doi.org/10.1016/j. jrurstud.2019.02.024

Zajda K. 2017. Wdrażanie innowacji społecznych przez wiejskie organizacje pozarządowe. Wieś i Rolnictwo 4(177), 97-114.

Zhu X. 2016. GIS for Environmental Applications: A Practical Approach. London: Routledge. https://doi.org/10.4324/9780203383124

\section{Netografia}

ESRI, 2018. How To: Calculate feature centroids. Online: https://support.esri.com/en/technicalarticle/000011754 (dostęp: 6.05.2020).

ESRI, 2019. Modeling spatial relationships. Online: https://pro.arcgis.com/en/pro-app/tool-reference/spatial-statistics/modeling-spatial-relationships.htm (dostęp: 23.01.2020).

Faber J.W., Sharkey P. 2015. Neighborhood effects. Online: www.sciencedirect.com/topics/computer-science/neighborhood-effect (dostęp: 26.01.2020).

Główny Urząd Geodezji i Kartografii. Dane z państwowego rejestru granic i powierzchni jednostek podziałów terytorialnych kraju - PRG. Online: www.gugik.gov.pl/pzgik/dane-bez-oplat/ dane-z-panstwowego-rejestru-granic-i-powierzchni-jednostek-podzialow-terytorialnychkraju-prg (dostęp: 20.01.2020).

Goszczyński W., Kamiński R., Knieć W., Woźniak A. 2013. Diagnoza rozwoju organizacji pozarządowych działających na obszarach wiejskich: Wyniki badań w projekcie „Dobry start”. Online: http://faow.org.pl/wp-content/uploads/2013/06/Diagnoza\%20-\%20blok\%20-\%20dp\%20 -\%202013-06-06.pdf (dostęp: 23.01.2020).

Mayhew S. 2005. Spatial Analysis \& Modelling. Online: https://researchguides.dartmouth.edu/gis/ spatialanalysis (dostęp: 20.12.2019).

Miró F. 2014. Routine Activity Theory. Online: https://onlinelibrary.wiley.com/doi/full/10.1002/ 9781118517390.wbetc198 (dostęp: 23.01.2020). 